\title{
Keynes at the Periphery:
}

\section{Currency hierarchy and challenges for economic policy in emerging economies}

\author{
Barbara Fritz ${ }^{*}$, Daniela M. Prates ${ }^{* *}$ and Luiz Fernando de Paula ${ }^{\star * *}$
}

\begin{abstract}
While the Post Keynesian literature offers a rather clear concept for growth-oriented policies, it is necessary to adapt them for peripheral emerging economies. We base our analysis of an appropriate Keynesian policy mix for these countries on the concept of currency hierarchy, where the currencies of peripheral emerging economies have a lower liquidity premium than the currencies of advanced economies. Under these conditions, we argue that domestic economic policy coordination should lay a major focus on a low policy rate and, especially, a competitive exchange rate for, at least, a balanced current account, in order to prevent capital flows boom-bust-cycles with subsequent financial crises and their damaging effects on employment and growth. We conclude that it is a rather ambitious and long term goal to climb up the currency hierarchy, especially under the current conditions of financial globalization.
\end{abstract}

Key-words: financial globalization; currency hierarchy; Keynesian policies

Resumo: Enquanto a literatura pós-keynesiana oferece recomendações de políticas orientadas para o crescimento bastante claras, é necessário adaptálas para as economias emergentes periféricas. Nesse artigo, a reflexão sobre a combinação de políticas keynesianas apropriada para essas economias baseia-se no conceito de hierarquia de moedas, na qual as moedas "emergentes periféricas" possuem um menor prêmio de liquidez do que as moedas dos países centrais. Sob essas condições, argumenta-se que a essa combinação deve ter como principais focos uma taxa de câmbio competitiva que garanta, ao menos, o equilíbrio da conta corrente, pré-condição para a prevenção de ciclos "boom-bust" de fluxos de capitais, que culminam em crises financeiras, com consequências negativas para o emprego e crescimento. Finalmente, conclui-se que é um objetivo bastante ambicioso e de longo prazo subir na hierarquia de moedas, especialmente sob as condições atuais de globalização financeira assimétrica.

Palavras-chave: globalização financeira, hierarquia de moedas, políticas keynesianas.

Área Anpec: Área 07. Economia Internacional

Classificação JEL: F3, F4, E6

\footnotetext{
Professor of Economics at the Institute for Latin American Studies at the Freie Universität Berlin; barbara.fritz@fu-berlin.de

Professor of Economics at the University of Campinas (Unicamp, Brazil) and CNPq researcher; daniprates@eco.unicamp.br.

Professor of Economics at the University of the State of Rio de Janeiro and CNPq Researcher; luizfpaula@terra.com.br
} 


\section{Introduction}

The Post Keynesian literature offers a rather clear concept for growth-oriented policies. This literature assumes that the establishment of monetary stability is far from being sufficient to assure growth, as uncertainty undermines market coordination towards equilibrium with full employment. Thus, the State should take an active role in several kinds of economic policies. Specifically, monetary, exchange rate, fiscal, labour and sectorial policies should be coordinated to assure monetary and financial stability as well as sustainable growth and employment.

This set of policies usually is formulated or in general, or for centre economies specifically. But is this also adequate for peripheral emerging economies ${ }^{1}$ ? These countries are not only characterized by a lower level of productive sophistication and diversification. The State's ability to pursue economic policies also seems to be more limited due to the different quality of their currencies, which are not accepted at the global level. Moreover, the negative consequences of this difference seem to be exacerbated by financial globalization.

In this paper, we ask if under these conditions the same set of Keynesian policies is adequate and feasible for centre and for peripheral emerging economies. What are the specific constraints faced by these economies to implement adequate policies for fostering sustainable growth? How Keynesian policies should be adopted in emerging economies under the environment of financial globalization?

Our main argument is that the international asymmetry related to the currency hierarchy, amplified by financial globalization, imposes major constraints to the adoption of Keynesian policies for these economies. Consequently, such policies should be adapted to allow for an increase of the policy space to pursue domestic policy goals, especially a competitive exchange rate and a low policy rate, pre-conditions for the ascension of their currencies in the global currency hierarchy in the long run.

Besides this introduction, the paper is organized as follows. Section 2 outlines the standard Post Keynesian approach to economic policy. In Section 3, we define the concept of currency hierarchy in general and under financial globalization. Sections 4 and 5 discuss the limits of and challenges for (Keynesian) economic policy, for emerging economies, followed by a brief conclusion.

\footnotetext{
${ }^{1}$ Here we define peripheral emerging economies as peripheral countries that are engaged in the context of financial globalization, which refers to the interpenetration of national monetary and financial markets with globalised markets (Chesnais, 1996, p.10-11). The terms "peripheral emerging", "emerging" and "developing" will be used interchangeably as well as "centre", "advanced" and "developed".
} 


\section{Keynesian economic policy}

Keynesian policies, in a broader sense, have as their main objectives the achievement of full employment and macroeconomic stability. According to the Post Keynesian approach, there is no endogenous mechanism in a monetary economy which ensures that economic activity tends to full employment (Arestis and Sawyer, 1998).

In a monetary economy, all assets, including money, have specific attributes that together determine their own rate of interest $\left(r_{a}\right)$, or their total expected return:

(1) $r_{a}=a+q-c+1$

where "a" is the expected appreciation, " $q$ " is the expected quasi-rent (or yield), " $c$ " is the carrying cost, and " $"$ " is the liquidity premium, which is the power of disposal that confers a potential convenience or security (Keynes, 1936, Ch.17).

Assuming perfect competition, assets with lower (higher) expected returns will be sold (purchased), until equalization of yields. As liquidity is strongly valued in times of higher uncertainty, the liquidity attribute (" $"$ ") is valued higher compared to the monetary returns $(q-c)$ in moments of higher uncertainty. The overall effect is a reduction in the demand for capital assets, resulting in the postponement of real investment plans. The concept of a monetary economy results in the possibility of effective demand failures, as non-producible money can dominate labour-using capital as a means to accumulate wealth. Under extreme uncertainty, to hold money or other liquid assets is a rational act since money provides flexibility to the agents in their portfolio due to its maximum liquidity (Carvalho, 1992).

In a monetary economy whose dynamics is determined by the non-neutrality of money and the principle of effective demand, economic policy is able to affect the real variables of the economy in the short and in the long run. In other words, nominal variables affect real variables in the long run because changes in the short term interest rate have permanent effects on investment decisions about capital assets (Arestis and Sawyer, 2006a). Thus, a Keynesian policy refers to economic policies designed to boost demand in order to raise demand prices of capital assets with respect to money. Economic policy should affect aggregate private investment, as it can create a safe environment that stimulates private agents to make more risky choices - that render profits and generate employment - than just accumulating liquid assets. The objective of economic policy in this approach is related to macroeconomic stability, a broader concept than just price stability, as it aims to reduce the uncertainties that are intrinsic to business.

In order to reach multiple policy objectives - such as economic growth and price stability- it is necessary to have a greater co-ordination of macroeconomic policies (fiscal, monetary, exchange rate, and income policies). Specific policies should never be implemented in isolation from other policies. A credible, wellcoordinated and workable Keynesian economic policy would be one that: "(i) aims at unambiguous goals (economic growth, full employment and price stability) and leaves the least room for its tools to be used in contradiction with 
each other, or with other policy tools; (ii) makes use of tools suitable to its goals; and (iii) gives out clear signals to financial markets and entrepreneurs in order to stimulate them to act in the direction desired by the authorities" (Sicsú, 2001, p.673). Therefore, the success of Keynesian policies depends a great deal on private agents' belief in its effectiveness.

Monetary policy through interest rate management can have a significant impact on the level of economic activity by influencing private agents' portfolio composition in favour of both an increase in production (using current productive capacity) and the acquisition of capital goods. According to the Post Keynesian approach, as interest variations can have long-lasting effects over investment and small effects over the inflation rate, monetary policy should be conducted in a way to produce moderate changes in short-term rates in order to avoid negative effects on capital accumulation employment (Carvalho, 1992, p.38). Post Keynesian economists argue that "a monetary policy is required which ensures stability to the financial system and pitches interest rates as low as possible (...) for this may give some (possibly slight) stimulus to demand" (Arestis and Sawyer, 1998, p.189). The low elasticity of inflation to interest rates and the strong impact on investments decisions calls into question the relevance of controlling the inflation rate only by means of an interest rate policy, as advocated in the inflation targeting regime framework. Inflation is seen not as a monetary phenomenon (Davidson, 1994), but mostly as a symptom of a fight over income distribution (workers and capitalists), and of cost factors. Therefore, price stabilization policy should consider the nature of the inflation and can include the use of buffer stocks of certain essential products, the adoption of some sort of income policy, and in special cases the adoption of prudential credit controls as necessary to limit the rate of expansion of aggregate demand (Arestis and Sawyer, 2006b; Davidson, 1994).

As for fiscal policy, during the economic slowdown, when agents' expectations about the future have deteriorated, expansionary monetary policy can fail to stimulate an increase in the aggregate demand due to a rise in agents' liquidity preferences. Under such conditions, expansionary monetary policy should be complemented by expansionary fiscal policy. ${ }^{2}$

Regarding exchange rate policy, since the collapse of the Bretton Woods system, these have been excessively volatile. Exchange rates, under the conditions of capital mobility and high international capital flows, are increasingly determined by portfolio decisions of global investors, and are more related to short-run outlooks than to sustainable long term developments. When aiming at full employment, exchange rate volatility should be avoided. For this purpose, some Post Keynesians recommend an international monetary system with (i) fixed exchange rate, (ii) provisions to control capital flows, and (iii) trigger mechanisms for automatically adjusting balance of payment disequilibrium, shifting the burden of resolving trade imbalances on the surplus economies (i.e. Davidson, 1994). The main objective is to create a safe and

\footnotetext{
${ }^{2}$ For the sake of limited space, in the following we restrict our analysis to monetary and exchange rate policies, even if fiscal policies are a key element in a post Keynesian approach.
} 
flexible (more elastic) international monetary system to expand the global effective demand and the level of employment.

In the following, we seek to reformulate the Post Keynesian concept of macroeconomic policies by adjusting it to the specific monetary conditions of emerging economies. For this, we link the Post Keynesian perspective on uncertainty and the fundamental role of money with the concept of currency hierarchy, where emerging economies' currencies are placed at the bottom.

\section{Currency hierarchy under financial globalization}

In this section, besides defining the concept of currency hierarchy in general (Section 3.1), we contend that this hierarchy revealed itself even more deleterious to the countries whose currencies are placed at its lower end in the current international monetary and financial system which is characterised by an asymmetric financial integration (Section 3.2).

\subsection{Currency hierarchy}

In an open monetary economy, currencies are a class of asset traded in foreign currency markets. As with any other asset, agents hold them because they favourably price their total expected returns. Since currencies are held as a portfolio capital asset, equation (1) above can be used to represent this behaviour. For example, if $r_{a n}>r_{a m}$, then currency $n$ appreciates relatively to currency $m$. Thus, the process of price determination of these assets can be represented through the variables of this equation. Thus, we understand the variables $a, q, c$ and $/$ as attributes of currencies (Andrade and Prates, 2013).

Pricing of currency assets is peculiar due to their distinctive traits. Under the Keynesian assumption of uncertainty, short run capital gains govern transactions in the currency markets, and expectations concerning the future evolution of exchange rates are the main determinants of the current rates (Davidson, 1982; Harvey, 2009). In particular, variable $a$, the expected appreciation of the currency, will tend to be highly unstable and subjective. Variable c, the carrying cost, can be specified for currencies as the financial openness of a country.

Yet, in the case of emerging currencies, the volatility of variable $a$ tends to be higher due to their position at the lower end of the so-called currency hierarchy, which refers to as the existence of a centre-periphery structure ${ }^{3}$ in the international monetary system. This means that the international monetary system comprises a hierarchical and asymmetrical institutional arrangement, organized around a key currency, currently the US dollar. Indeed, Eichengreen et al (2007, p.160) point out that economic agents tend to concentrate international portfolios and markets in few major currencies - the dollar, euro, yen, pound, and Swiss franc -and have limited appetite for adding additional currencies for their portfolio. Cohen $(1998 ; 2004)$ adopts the concept of

\footnotetext{
3 The centre-periphery metaphor was introduced by the structuralist development economist Raúl Prebisch (1949). The 'peripheral condition' results from a given economy's structural insertion in the international division of labour, which can be seen as organized in two poles (Ocampo and Martin, 2003).
} 
"monetary pyramid" to classify the different types of currencies, which should be distinguished according to their degree of "monetary internationalization".

Under the Keynesian perspective adopted here, the key currency is placed at the top of the hierarchy because it has the highest degree of liquidity. The currencies issued by the other core countries are in intermediate positions, and are also liquid currencies, yet with a smaller degree of liquidity than the key currency. At the opposite end are the currencies issued by emerging countries, which are non-liquid currencies (Andrade and Prates, 2013). The liquidity premium of these currencies is lower than that of the key currency and of those in the middle, labelled here as Northern currencies $I_{s}<I_{n}(\mathrm{n}=$ North, $\mathrm{s}=$ South).

Thus, to compensate for the lower liquidity premium, these currencies have to offer a higher q, which is a policy variable, try to achieve a higher a, thus create conditions which are attractive for international investors, and/or reduce c, i.e. the obstacles for capital inflows. Only under these conditions the exchange market can come to equilibrium:

(1) $a_{n}+q_{n}-c_{n}+l_{n}=a_{s}+q_{s}-c_{s}+l_{s}$

The currency hierarchy is a fundamental feature of the international monetary systems that came before in history inasmuch since the sterling-gold standard a national currency has performed the role of international currency. As Flandreau and Sussmann (2005) show, international bonds of Latin American countries, from the beginning of the creation of domestic currencies due to political independence in the early $19^{\text {th }}$ century, even if denominated in their domestic currencies, contained gold clauses, giving them the characteristics of foreigncurrency denominated debt. This is what Eichengreen and Hausmann (2005) label the 'original sin' - a country's inability to borrow abroad in own.

However, currently, this hierarchy revealed itself even more deleterious to countries whose currencies are placed at its lower end due to the characteristics of the international monetary system that has came out after the collapse of the Bretton Woods Agreement, in 1971-1973, as detailed below.

\subsection{Asymmetric financial integration}

The main features of the current international monetary and financial system are: (i) the fiduciary dollar as the key currency, on the top of the currency hierarchy; (ii) the floating exchange rate regime; (iii) almost free capital mobility; (iv) the dynamics of the current international financial system, governed by financial globalisation (Prates, 2005).

As Keynes (1980b) stressed during the Bretton Woods debates, the characteristics of the international monetary system shape the profile of the international financial system. The interplay between the fiduciary and flexible key-currency and the high capital mobility environment has fostered financial market integration and financial innovations (securitization, derivatives, etc.), leading up to the financial globalization setting. This setting, in turn, has been marked by higher volatility, with capital flows, exchange rates, interest rates and assets prices subject to large short-run fluctuations and a high degree of contagion, with financial turbulence spreading from the epicentre of the system 
to countries and markets that apparently have no connection with the original problem (even to those considered to have "sound" macroeconomic policies) (Chesnais, 1996; Bryan, 1999).

Yet, the international financial integration process is also asymmetric. Emergent countries have become even more vulnerable to the inherent volatility of capital flows, which ultimately depend on exogenous sources. In bust phases, by virtue of changes in the monetary policy in the centre and/or increase in the international liquidity preference, their currencies and financial assets are the first to be sold due to their position at the lower end of the currency hierarchy. In other words, they turn up the main victims of the global investors' "flight to quality" because their lowest I and, consequently, their inability to function as store of value (Andrade and Prates, 2013). Furthermore, the still-marginal insertion of currencies and financial assets of emerging economies in the portfolios of these investors since the 1990s has also contributed to this process (Obstfeld and Taylor, 2004).

The potentially destabilising effects of these flows on their financial markets and exchange rates are significant. As in most of these countries financial markets are not as liquid and deep, sales by foreign investors significantly reduce securities prices, affecting the financial position of domestic debtors, besides its direct effect on residents' external debt (Studart, 2003; Griffith-Jones, 1995).

Some mainstream economists have also highlighted the boom and bust pattern of capital flows, although they not take into account the hierarchical character of the current international monetary system. According to the recent analysis carried out by Rey (2013), this pattern is determined by a global financial cycle, which depends mainly on monetary conditions in the centre country. These monetary conditions are transmitted to the rest of the world through gross credit flows and leverage, irrespective of the exchange rate regime. This channel, in turn, invalidates the traditional "trilemma" (i.e., "impossible trinity") view of the open economy, upon which in a world of free capital mobility, independent monetary policies are possible only if exchange rates float.

\section{Limits of economic policy in emerging economies}

In the following, we discuss the limits to exchange rate (section 4.1) and monetary (section 4.2) policies of emerging countries that stem from the position of their currencies at the lower end of the currency hierarchy. As we will explore in the sequence the international asymmetry related to the currency hierarchy, extrapolated by financial globalization, imposes major constrains to the adoption of Keynesian policies for emerging economies.

\subsection{Exchange rate policy}

The policies of managed exchange rate adopted by peripheral emerging countries in the late 1980s and 1990s proved highly vulnerable to speculative attacks and culminated in successive currency crises. In most countries, these policies were replaced by de jure floating exchange rates. However, in practice domestic monetary authorities try to curb the volatility of their exchange rates 
through active intervention in currency markets. What drives the systematic interventions of central banks in the peripheral emerging economies' currency markets (the "fear of floating", cf. Calvo and Reinhart, 2002) is the need to contain the excessive volatility of exchange rates (see Section 3.2). This defensive behaviour is manifested through attempts to reduce external vulnerability by pre-emptive accumulation of foreign reserves -for the purpose of meeting unforeseen requirements- and/or by curbing the tendency of currency overvaluation during boom in capital flows (Aizenman et al, 2004; Carvalho, 2010). After the global financial crisis of 2008, several emerging economies have also introduced capital account regulations in response to the new boom in capital flows, which came out with huge currency appreciation pressures and risk of credit and asset price booms (IMF, 2012; Fritz and Prates, 2014).

The Post Keynesian literature (Schulmeister, 1988; Davidson, 2000; Harvey, 2009) has already highlighted that short-term capital flows and expectations about differentials of yields and/or liquidity constitute the key determinants of exchange rates. Yet, in the case of emerging economies which have their currencies placed at the lower end of the currency hierarchy, the volatility of capital flows is higher than for centre economies and these flows are even more sensitive to the monetary policy in the centre (see Section 3.2). As exchange rates are more volatile, frequent interventions by the central banks are required, which, in turn, reinforce the interaction between the exchange rate and the policy rate. Therefore, the loss of monetary autonomy in a context of free capital mobility is greater.

Further, for peripheral emerging economies, macroeconomic challenges are not restricted to monetary policy, but also encompass exchange rate policy inasmuch the volatility of the exchange rate is harmful due to its negative impacts on growth, financial fragility and inflation (Flassbeck, 2001). Exchange rates are particularly vulnerable to the inherent volatility of capital flows, ultimately determined by an exogenous process. As already mentioned (section 3.2), at points of reversal of the cycle, of monetary policy changes in the centre or of increase in the liquidity preference, emerging financial assets are the first victims of the global investors' "flight to quality", as they cannot a safe haven under uncertainty on a global scale. In this setting, the liquidity premium I and the expected appreciation a are of utmost importance, since it is by means of their assessment that agents in currency markets take decisions regarding which assets to demand. If investors leave these countries swiftly, this may deteriorate / even more, placing further pressure on local policy-makers to raise the interest rate (with the aim of increasing $q$ and a), as well as to deepen the financial openness (namely, remove capital controls) to reduce $c$. (Andrade and Prates, 2013). If this policy is successful, $(a+q-c)$ will increase to compensate the lower liquidity premium I (see section 3.1). As Grabel (1996, p. 1763) stressed, the movement of portfolio investment induced by these policies produce two harmful outcomes: "the exacerbation of constraints on policy autonomy; and the increased vulnerability of the economy to risk, financial volatility and crisis"

On the other hand, in periods of capital flows' boom, when the appetite for risk is higher, emerging assets become objects of desire on the part of global investors because of the expectation of appreciation (increase in a) of their 
respective currencies (associated with the favourable interest rate differential and/or with the perspective of capital gains in the stock markets, which increase $q)$, compensating for their reduced liquidity premium $I$.

Yet, higher capital inflows, in the form of increased external debt, and/or higher portfolio investments put pressures towards the appreciation of the domestic currency, causing boom-bust cycles of credit and capital inflows and the subsequent need to further increase the interest rate.

\subsection{Monetary policy}

The proper concept of currency hierarchy requires a specific policy to compensate the difference between the liquidity premiums of currencies. One option would be to increase the carrying costs $c_{s}$, especially with regards to capital outflows, in order to enable a difference $q_{s}-q_{n}$ lower than $I_{s}-I_{n}$. Yet, this kind of capital account regulation and low interest rate policy is difficult to succeed when there is devaluation expectations attached to this peripheral currency, i.e. a low $a_{s}$. When currency devaluation expectations are predominant, market actors will urgently seek to circumvent outflow controls in order to prevent future income and wealth losses.

The other option is the orthodox receipt of increasing the interest rate to compensate for the lower liquidity premium. This makes domestic investment and growth dependent from capital inflows. This growth by external debt may in the best case increase domestic investment, however does cause an appreciation of the domestic currency, decreasing international competitiveness. This makes the growth process unsustainable in the medium term, as amounting external vulnerability creates devaluation expectations and, at some moment, the reversal of capital flows which may cause a financial crisis in the emerging economy (Riese, 1997).

One important factor that also contributes for higher interest rates in peripheral emerging countries is the fact that some traditional transmission channels of monetary policy do not work well in most of them compared to centre economies. Firstly, the credit channel is less effective due to the smaller ratio credit to private sector-to-GDP. Second, the low development of capital market makes domestic expenditure less sensitive to wealth effect. Third, as for the exchange rate channel, exchange rate volatility is higher in emerging economies (see section 4.1) and additionally evidences show that exchange rate pass-through has tended to be stronger in such economies ${ }^{4}$ (Mohanty and Scatigna, 2005); therefore, as exchange rate movements play a more prominent role than in advanced economies, central banks rely often on interest rate interventions to stem exchange rate volatility.

For all these reasons, monetary policy in emerging countries should be more tightened than in centre economies in order to affect aggregate demand, what means that the sacrifice ratio of deflationary policy is frequently higher. An additional problem for emerging economies is their greater vulnerability to external shocks than advanced ones due to specificities of their external

\footnotetext{
${ }^{4}$ The main reason is that income is negatively and significantly correlated with passthrough as lower income economies have a larger portion of traded goods in the households' consumption basket.
} 
insertion: empirical studies show that the impact of external shocks on domestic inflation is more intensive in emerging economies than in advanced ones ${ }^{5}$, what can contribute for a higher inflation rate compared to developed economies.

These specificities of monetary policy in peripheral emerging countries make the implementation of inflation targeting regimes (ITR) - adopted by an increasing number of these countries since beginning of the 1990s - even harder than in advanced ones.

Indeed, even the standard literature recognizes that emerging countries face particular challenges when put in place ITR due to (i) their higher pass-through (see above), (ii) the greater difficulty in forecasting inflation, because shocks are larger and have stronger effect, the productive diversification is lower and domestic financial markets are shallower, (iii) their external liabilities are overwhelmingly denominated in external currency (original sin), creating a problem of 'fear of floating', and (iv) many emerging economies have a credibility problem regarding monetary policy, which at least partially are interdependent with these structural features (Eichengreen 2002; Mishkin, 2008).

Yet, there is an additional specific feature of ITR which applies under the condition of an open capital account, and that further complicates the achievement of a competitive and stable exchange rate, thus perpetuating the problem of the low position in the currency hierarchy. The problem is that a nominal appreciation of the currency is much more credible for a central bank committed to inflation targeting than depreciation, due to the negative effect of the latter on inflation through its pass-through effect. Indeed, empirical evidence shows that in many emerging countries that adopt ITR central banks make use of deliberate asymmetric policy with respect to the exchange rate, as they avoid sharp currency depreciation and tend to tolerate currency appreciation as it contributes to the achievement of the inflation targets. Thus, under ITR, actors at the currency market internalize the expectation that the central bank has an inclination towards currency appreciation, giving it highly asymmetric power to influence the exchange rate, and creating an upward trend which may further exacerbate exchange rate volatility and related boom bustcycles (Kaltenbrunner, 2011).

It is worth mentioning that most empirical literature that compares inflation and output performance between emerging economies that adopt and that do not adopt ITR show no conclusive evidences that the first group performs better and that the differences between the two groups of countries with respect to inflation performance appears small (Brito and Bystedt, 2010). Indeed, the relatively low inflation of early 1990s until 2008 may be mostly related to the impact of the entry of China and other emerging countries that produces industrialized products at low costs.

We conclude this section with two lessons for our discussion. The first one is the higher vulnerability to external shocks of peripheral emerging countries than centre countries turns out such economies more prone to cost-push inflation.

\footnotetext{
${ }^{5}$ Mohanty and Klau (2001), analyzing the experience of 14 emerging countries during the 1980s and 1990s, found that external supply shocks, in special food and energy prices, are important determinants of domestic inflation.
} 
The second lesson is that exchange rate movements pose some essential challenges to emerging economies' monetary authorities, considering the strong influence of the exchange rate on domestic inflation in these countries and also the effects of exchange rate volatility on real variables. While the higher vulnerability to external shocks is associated with the very peripheral condition, the essential challenges posed by exchange rate movements stem from, in the last resort, the position of their currencies at the lower end of the currency hierarchy.

\section{Currency hierarchy and Keynesian economic policies for emerging economies}

In this section we discuss the implementation of Keynesian policies for emerging economies under the conditions of currency asymmetries and financial globalization, with special focus on exchange rate policies (section 5.1) and growth policies combined with the reduction of interest rate differential and macroeconomic stability (section 5.2). Such policies should be adapted to allow for an increase of the policy space to pursue in the short and medium run domestic policy goals, especially a competitive exchange rate, pre-condition for the ascension of their currencies in the global currency hierarchy in the long run.

\subsection{Exchange rate policies}

The literature that discusses what should be the most appropriate exchange rate regime for peripheral emerging economies has not considered one key issue stressed by Keynes: the adverse consequences of the position in the currency hierarchy for the degree of macroeconomic policy autonomy.

Indeed, one of the central elements of Keynes' proposal at the Bretton Woods Conference was to reduce the asymmetries between creditor and debtor countries, avoiding macroeconomic instability and deflationary adjustments that hindered economies from achieving full employment (Keynes, 1980a, Davidson, 1992/93). In today's world, a reform of the international monetary system as proposed by Keynes would benefit, mainly, the emerging countries. However, this sort of reform still seems to be a "monetary utopia". We thus ask what could be the most appropriate macroeconomic regime for allowing emerging economies to achieve full employment and macroeconomic stability.

As in this system the hierarchy among currencies engenders structural exchange rate volatility (higher a) in emerging peripheral economies, the issuers of non-liquid currencies (lower $\eta$ ), the choice of the exchange rate regime is of utmost importance. In the short run (currency hierarchy unchangeable), the exchange rate policy can mitigate the negative consequences of the system's asymmetries through its influence in the attributes $a$ and $c$, while the monetary policy can affect the attribute $q$ (see section 5.2).

We agree with other Post Keynesian authors which support that some sort of managed floating exchange rate regime would be the best option for most peripheral emerging economies (Ferrari-Filho and Paula, 2009; Frenkel, 2006). Differently from a pegged/semi-pegged exchange rate, authorities' interventions 
to limit exchange rate movements may not target a certain level of the exchange rate, allowing the nominal exchange rate to float in order to disincentive speculative capital flows. . Therefore, a managed floating exchange rate regime can contribute to the fall in the volatility of $a$. The exchange rate policy under the managed floating regime should also aim at influencing the exchange rate path. The preservation of a competitive and stable real exchange rate can be used as an intermediate target of macroeconomic policies oriented to employment and growth objectives (Frenkel, 2006). This is because it is a pre-condition for obtaining trade and current account surplus, which would come out with lower external constraints to economic growth and greater policy space to pursue Keynesian policies.

A competitive and stable exchange rate is the main target that peripheral emerging economies should pursue to achieve external competitiveness. The subordination of the exchange rate for the aim of price stability both in the case of a pegged exchange rate or an inflation targeting regime is highly problematic from this perspective. Price stability should rather be achieved by coordinated monetary, fiscal and income policies.

Even if the attribute $I$ is rather unchangeable in the short run, the accumulation of trade and current account surpluses at the medium term is a necessary (but not sufficient) condition to change this attribute. A low level of net external debt, combined with export surpluses, may be able to create medium term currency appreciation expectations, which would come out with an increasing demand for this currency. This can lead to a sustained increase of $a$, thus giving room to lower the policy rate $q$. The subsequent higher growth rates, together with currency appreciation expectations, may in the long term enable this peripheral currency to climb the global hierarchy, allowing gradually the country to issue external debt in its own currency. A pre-condition for this rise, however, is that there are other economies absorbing cumulative trade and current account deficits. In a stable international monetary regime, this could be the case for the hegemonic currency. Other economies will suffer the consequences of cumulative destabilization due to subsequent trade and current account deficits (Riese, 2004).

Yet, a crucial question still needs to be answered: Which tools have peripheral emerging economies available to reach the aforementioned target of the exchange rate policy in the current hierarchical and asymmetrical international monetary system?

The effectiveness of the monetary authorities' interventions in the currency market depends on the size of foreign reserves and on the degree of financial openness. Indeed, central banks of peripheral emerging countries, should act as market makers in their currency markets, in order to influence the exchange rate path. Yet, the larger the foreign reserves and the lower the degree of financial openness (i.e, the broader the capital account regulation - higher $c$ ), the greater their capacity to reduce the volatility of $a$ and to influence the exchange rate path.

Therefore, the "self-insurance" strategy of foreign reserves accumulation and capital account regulation should be seen as complementary tools of the exchange rate policy. This strategy would amount to a defensive response by 
emerging economies which enhance the central banks capacity to counter speculative attacks against their currency as well as boost the effectiveness of their interventions in the currency market in normal times with the aim at maintaining a stable and competitive exchange rate. Moreover, the very accumulation of foreign reserves contributes to the net external debt fall. Thus, this defensive response would result in a lower volatility and a sustained increase of $a$, favouring to the process of climbing the currency hierarchy and, eventually, to the rise in the liquidity premium I of their currency. On their turn, capital account regulation work as a "filter" that soften the effects of fickle capital flows (Greenville, 2000), enlarging the room of manoeuvre of the exchange rate policy through its impact on the attribute $c$ (the broader the capital account regulation, the higher will be $c$ ). Therefore, despite the advances made by the IMF (2012), its new framework on capital flow management does not provide the necessary policy space for emerging economies inasmuch the IMF still supports financial liberalization in these economies as a final goal, and set bounds to their policy space. On the contrary, we support herein that capital account regulation should be a permanent part of these countries' exchange rate regime and, thus, of their overall macroeconomic regime (Fritz and Prates, 2014).

\subsection{Policies to achieve macroeconomic stability and to reduce interest rate differential}

Of particular interest in our discussion is the following question: How can an emerging economy create conditions for alleviating pressure on monetary policy, as the lower liquidity premium has to be compensated by higher interest rates? A reduction in the interest rate if achieved could contribute to increase the liquidity premium ( $I$ of this economy (equation 2 ).

The tendency for a higher interest rate could be offset by regulation of capital flows, by driving a wedge between onshore and offshore interest rates in order to provide monetary authorities some policy autonomy. In particular, the combination of foreign exchange reserves and some capital account regulation can contribute for a greater stability in the foreign exchange market as financial agents would have the perception that economic authorities have enough instruments to reduce the volatility of capital flows, and doing so can contribute for reducing the exchange rate risk and, consequently, the domestic interest rate.

Further, the attachment of a stronger and sustained surplus in trade and current account balance by reducing the country's necessity of foreign capital could be a structural factor for the fall in domestic interest rates, as it reduces the necessity of high interest differential to attract capital inflows. This is one of the main reasons why most East Asian developing countries have decreased significantly their interest rates compared to Latin American ones.

Measures to stimulate the development of domestic financial markets by diversifying firms' financing sources can help to reduce country's external vulnerability and also to strengthen some traditional transmission mechanisms of monetary policy (see section 4.2) to allow a reduction in the level of interest rates. Of paramount importance are government's efforts to reduce reliance on indexed-public debt and at the same time to increase public financing through fixed rate bonds, leading to the development of a long-term yield curve. In 
particular, macroeconomic stability favours government's efforts to improve public debt and corporative bonds market. Greater access to domestic financing derived from the development of the domestic bonds market can contribute for the reduction of currency mismatches and can consequently reduce problems related to the "original sin" (Mohanty, 2012). In short, the combination of low interest rates (to support investment in fixed capital) with low and relatively stable exchange rate (supportive to export growth), besides the implementation of a countercyclical and flexible fiscal policy, would stimulate entrepreneurs to make more risky choices than just accumulating liquid assets.

For the reasons that we have explored elsewhere in this paper, ITR is not the most appropriate economic policy framework for peripheral emerging countries. Their central banks should have a double target: employment and inflation. As for the inflation target, we should consider some issues.

First, if monetary authorities have more than one goal they need more than one tool (Tinbergen's theorem), that can include, among others, macro-prudential policies, including prudential credit controls (for instance, with the use of public banks), and financial regulation. Due to the effects of the interest rate over investment decision in capital assets, the use of interest rate for price stabilization purposes should be avoided, and alternatively a broader and pragmatic policy should be used for such goal, depending on the characteristic of each type of inflation. As emerging economies are more vulnerable to supply shocks, a pragmatic policy should include the use by government of buffer stock of some essential products, the management of administrative prices (such as private health plans), and/or some stability of the exchange rate (at a level that not jeopardize the external competitiveness). The implementation of some sort of income policy could contribute to 'anchor' prices: for instance, the adoption of internal rules for nominal wage growth, which could follow productivity growth plus some inflation index. Indeed, adjustment of real wages to productivity can work as a sustainable stabilizer of domestic demand (Flassbeck, 2014), and at the same time can be used as a policy of gradual real wage gains inasmuch in a lot of peripheral emerging countries wage bargain is weak.

Second, empirical studies about 'optimum' intervals of inflation show the existence of a non-linear relation between inflation rate and economic growth. Most studies found critical levels higher to emerging economies than to advanced ones ${ }^{6}$. One of the reasons is that a higher rate of GDP growth in the former generates a higher rate of increase in non-tradable goods' prices relative to developed countries. Based on this reasoning we can state that the catchingup of emerging countries to developed countries demands, amongst other reasons, different target levels of inflation. Very low targets can compromise economic growth in such economies.

\section{Conclusion}

In this paper we analysed how the set of Post Keynesian policies formulated to pursue the goal of full employment should be adjusted for the case of emerging

\footnotetext{
${ }^{6}$ Khan and Sehadji (2001), for instance, found critical levels above of which inflation decreases significantly economic growth between 1-3\% p.a. for industrialized countries and $11-12 \%$ p.a. for developing countries.
} 
economies under the conditions of an asymmetric global monetary and financial order. Within the global currency hierarchy, the currencies of peripheral emerging economies are characterized by a lower liquidity premium than the currencies of centre economies, which is severely damaging for a sustained growth process. Under these conditions, we argue that economic policy coordination should lay a major focus on exchange rate policies. It seems to be relevant to avoid an appreciation of the domestic currency beyond a level which allows at least for a balanced current account in order to prevent capital flows' boom-bust-cycles with subsequent financial crises and their damaging effects on employment and growth. In order to attain such goal, it is important to sustain a stable and low interest rate alongside the strategies of foreign reserves accumulation and capital account regulation.

The maintenance of an exchange rate aim for an equilibrated current account is already a rather complex task which requires supportive monetary policy, but also fiscal and wage policies. Policy coordination certainly is a key issue here, especially to relieve monetary policy while at the same time maintaining a moderately low level of inflation, and to create policy space for fiscal countercyclical policies.

If this kind of policy set already is rather ambitious, this holds even more for policy prescriptions to climb up the currency hierarchy. Here, certainly further research in terms of country studies is required. There is an additional challenge, as a key condition here seems to be the accumulation of trade and current account surpluses. This, however, depends on the ability and willingness of other economies to accept the counterpart of cumulative trade and current account deficits. It thus seems that not all countries can climb the ladder of the currency hierarchy at the same time, especially without others declining.

\section{References}

Aizenman, J., Lee, Y. and Rhee, Y. (2004) "International reserves management and capital mobility in a volatile world: Policy considerations and a case study of Korea". NBER Working Paper No. 10534.

Andrade, R. and Prates, D. M (2013).“Exchange rate dynamics in a peripheral monetary economy”. Journal of Post Keynesian Economics, vol. 35, 399416.

Arestis, P. and Sawyer, M. (1998). "Keynesian economic policies for the new millennium". The Economic Journal, vol. 108, 181-195.

Arestis, P. and Sawyer, M. (2006a). "Interest rates and the real economy". In: Gnos, C. and Rochon, L.P. (eds.). Post Keynesian Principles of Economic Policy. Aldershot: Edward Elgar.

Arestis, P. and Sawyer, M. (2006b). "The nature and role of monetary policy when money is endogenous". Cambridge Journal of Economics, v. 30, 847-860.

Bryan, D. (1999) “Internationalization of Capital." In P.A. O'Hara (ed.), Encyclopedia of Political Economy, vol. 1. London: Routledge, 1999. 
Brito, R.D. and Bystedt, B. (2010). "Inflation targeting in emerging economies: Panel evidence". Journal of Development Economics, vol.91, 198-210.

Calvo, G. and Reinhart, C. (2002) "Fear of floating". Quarterly Journal of Economics, vol. 117, no. 2, 379-408.

Carvalho,F.J.C. (1992).Mr Keynes and the Post Keynesians.Cheltenham: Edward Elgar.

Carvalho, F. J.C. (2010) "The accumulation of international reserves as a defense strategy". In: Griffith-Jones, S., Ocampo, J.A. \& Stiglitz, J.(2010) (eds.) Time for a Visible Hand: Lessons from the 2008 World Financial Crisis. Oxford: Oxford University Press.

Chesnais, F. (1996) “Introduction générale". In: Chesnais, F. (ed.) La Mondialisation Financière: Genèse, Coût et Enjeux.Paris: Syros.

Cohen, B. J. (1998). “The Geography of Money". Ithaca, Cornell University Press.

Cohen, B. J. (2004). "The Future of Money”. Princeton, NJ: Princeton University Press.

Davidson,P. (1982) International Money and the Real World. New York: Wiley.

Davidson,P. (1994). Post Keynesian Macroeconomic Theory. Cheltenham: Edward Elgar.

Davidson, P. (2000) "Liquidity vs. efficiency in liberalized international financial markets: a warning to developing economies". Revista de Economia Política, vol. 20, no. 3, 3-21.

Eichengreen, B. (2002). Can Emerging Markets Float? Should they Inflation Target? Banco Central do Brasil Working Paper No. 36.

Eichengreen, B. and Hausmann, R. (2005) (eds) Other People's Money - Debt Denomination and Financial Instability in Emerging Market Economies, Chicago: University of Chicago Press.

Eichengreen. B., Hausmann, R., and Panizza, U. (2007). "Currency mismatches, debt intolerance, and the original sin: Why they are not the same and why it matters". In Edwards, S. (ed.). Capital Controls and Capital Flows in Emerging Economies. Chicago: University of Chicago Press.

Ferrari-Filho, F.and Paula, L.F. (2009). "Exchange rate regime proposal for emerging countries: a Keynesian perspective". Journal of Post Keynesian Economics, vol. 31, 227-248.

Flandreau, M. and Sussmann, N. (2005)."Old sins - exchange clauses and European foreign lending in the nineteenth century". In: Eichengreen, B. 
and Hausmann, R. (eds.). Other People's Money. Chicago: University of Chicago Press.

Fritz B. and Prates, D (2014). "The new IMF approach to capital account management and its blind spots: lessons from Brazil and South Korea". International Review of Applied Economics, v.28, 210 - 239.

Flassbeck, H. (2001). "The exchange rate - market price or economic policy tool", UNCTAD Discussion Paper, n. 149.

Flassbeck, (2014)."Competitive exchange rates and macroeconomic theory". In Bresser-Pereira, L.C., Kregel, J., and Burlamaqui, L.(ed.). Financial Stability and Growth: Perspectives on Financial Regulation and New Developmentalism. Abington: Routledge.

Frenkel, R. (2006). "An alternative to inflation targeting in Latin America: macroeconomic policies focused on employment". Journal of Post Keynesian Economics, vol. 28, no.4, 573-591.

Grabel, I. (1996). "Marketing the Third World: The contradictions of portfolio investment in the global economy". World Development, vol. 24, no. 11, 1761-1776.

Greenville, S. A. (2000). "Exchange rate regimes for emerging markets". Reserve Bank of Australia Bulletin. Sydney: Reserve Bank of Australia, November.

Griffith-Jones, S. (1995) "Globalización de los mercados financieros y el impacto de los flujos hacia los países en desarrollo: Nuevos desafíos para la regulación". Pensamiento Iberoamericano, vol. 27, 41-76.

Harvey, J. T. (2009) Currencies, Capital Flows and Crises: A Post Keynesian Analysis of Exchange Rate Determination. London: Routledge.

IMF (2012). The Liberalization and Management of Capital Flows - An Institutional View, at:

http://www.imf.org/external/np/pp/eng/2012/111412.pdf (last access 03/18/2013).

Kaltenbrunner, A. (2011). Currency Internationalization and Exchange Rate Dynamics in Emerging Markets: A Post-Keynesian analysis of Brazil. (PhD Thesis), School of Oriental and African Studies (SOAS), University of London.

Keynes, J.M. (1936). The General Theory of Employment, Interest, and Money. London: Palgrave Macmillan.

Keynes, J.M. (1980a). Activities 1940-46 Shaping the Post World: Employment and Commodities. Collected Writings of John Maynard Keynes, vol. XXVII. London: Macmillan. 
Keynes, J. M. (1980b). The Collected Writings of John Maynard Keynes, v. XXV, activities 1940-44: Shaping the Post-War World, the Clearing Union, D. Moggridge (ed.). London: Macmillan.

Khan, M. And Senhadji, A. (2001). "Threshold effects in the relationship between inflation and growth". IMF Staff Papers vol. 48, no. 1, 1-21.

Mishkin, F. S. (2008). "Challenges for inflation targeting in emerging market countries". Emerging Markets Finance And Trade, vol. 44, no. 6, 5-16.

Mohanty, M. (2012). "Fiscal policy, public debt and monetary policy in EMEs: an overview". BIS Papers no 67, October.

Mohanty, M., and Klau, M. (2001). "What determines inflation in emerging market economies?" BIS Papers n. 8. Basle: Bank for International Settlements.

Mohanty, M., and Scatigna, M. (2005). "Has globalization reduced monetary policy independence?" BIS Papers n. 23. Basle: Bank for International Settlements.

Obstfeld, M. and Taylor, A. M. (2004).Global Capital Markets - Integration, Crisis, and Growth.Cambridge: Cambridge University Press.

Ocampo, J. A. and Martin, J. (2003) Globalization and Development: A Latin American and Caribbean Perspective. Palo Alto (CA): Stanford University Press.

Prates, D. M. (2005). "As assimetrias do sistema monetário e financeiro internacional". Revista de Economia Contemporânea, vol. 9, no. 2, 263288.

Prebisch,R.(1950). The economic development of Latin America and its principal problems. New York: United Nations Department of Economic Affairs, mimeo.

Rey, H. (2013). "Dilemma not trilemma: The global financial cycle and monetary policy independence". London Business School, CEPR and NBER, Jackson Hole Symposium.

Riese, H, (1997): Stabilität und Entwicklung - Anmerkungen zur Integration der Dritten Welt in die Weltwirtschaft, in: Braig, M., Ferdinand, U. and Zapata, M. (eds.) Begegnungen und Einmischungen: Festschrift für Renate Rott zum 60. Geburtstag, Stuttgart: Akademischer Verlag,

Riese, H. (2004) "Development strategy and economic theory: comments on a Neglected Topic". In: Hölscher, J. and Tomann, H. (ed.). Money, Development and Economic Transformation. Selected Essays, London/New York: Palgrave.

Schulmeister,S. (1988) "Currency speculation and dollar fluctuations". Banca Nazionale Del Lavoro Quarterly Review, December. 
Sicsú, J. (2001). "Credible monetary policy: a Post Keynesian approach". Journal of Post Keynesian Economics, vol. 23, no. 4, 670-686.

Studart, R. (2003). "A integração de parceiros desiguais: os efeitos desestabilizadores da liberalização financeira e a internacionalização das economias latino-americanas". In: Ferraz, J. C., Crocco, M. and Elias, L.A. (ed.) Liberalização Econômica e Desenvolvimento. São Paulo: Futura. 